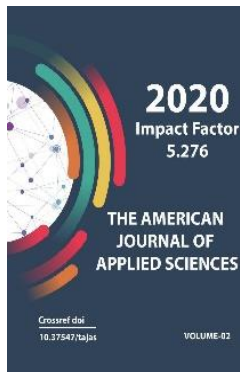

Journal Website: http://usajournalshub.c om/index,php/tajas

Copyright: Original content from this work may be used under the terms of the creative commons attributes 4.0 licence.

\section{The Interactive Map Of Samarkand City As New Cartographical Source}

\section{Rakhmonov Dilshod Nurboboevich}

Phd Student Of The Faculty Of Geography And Natural Resources, National University Of Uzbekistan Named After Mirzo Ulugbek, Tashkent, Uzbekistan.

\author{
Yakubov Gayrat Zaidovich \\ Phd Student Of The Faculty Of Geography And Natural Resources, National University Of \\ Uzbekistan Named After Mirzo Ulugbek, Tashkent, Uzbekistan.
}

\section{Yusupjonov Otabek Goibnazarovich \\ Teacher Of The Faculty Of Geography And Natural Resources, National University Of Uzbekistan Named After Mirzo Ulugbek, Tashkent, Uzbekistan.}

\author{
Nosirov Bakhtiyorjon Ikhtiyorjonovich \\ Master Of The Faculty Of Geography And Natural Resources, National University Of Uzbekistan \\ Named After Mirzo Ulugbek, Tashkent, Uzbekistan. \\ Anvarov Shukurullokhon Maksudhon Ugli \\ Master Of The Faculty Of Geography And Natural Resources, National University Of \\ Uzbekistan Named After Mirzo Ulugbek, Tashkent, Uzbekistan.
}

\title{
ABSTRACT
}

Currently, interactive maps are being created and widely used in most developed countries. Interactive maps allow to solve a variety of socio-economic problems. The article discusses an interactive map available on the tourism.ru online platform, its advantages and issues of use. In particular, information about objects that are important for tourists - hotels, historical and cultural monuments, is presented on the example of an interactive tourist map of the city of Samarkand.

\section{KEYWORDS}

Interactive map, historical and cultural monuments, Samarkand, internet, tourism.

\section{INTRODUCTION}

We live in the 21st century in the age of technology and information. Because we have mobile devices (gadget, device), home computers and TVs, office and computer software, office equipment and technology, unique technology in educational institutions, 
and other high-tech nanotechnologies. Without them, it is difficult to imagine the development and the great future $[1,2]$.

In fact, the whole world is represented by a single cell phone. It is possible to communicate with a person from any part of the world through various social networks. In addition, you can search for any destination via Yandex, GoogleMap and other online maps. Various types of information can be found quickly and widely used on the Internet [5].

Nowadays the Internet and modern software are effectively used in creating and using maps. An example is interactive maps. Interactive maps are one of the most advanced stages of cartography and geoinformatics, and nowadays most countries have created interactive maps on a variety of topics and are viewed as one of the most important sources for solving various problems[2].

\section{METHODOLOGY}

Nowadays, in many developed countries, interactive maps of various topics are being created for different purposes. Most of these maps are open to access. As an example, consider a tourist map created in Russia.

There is a website on the Internet located at http://www.turizm.ru, which includes interactive maps of many countries with information about tourism. To get information on the tourist potential of a particular country very simple. It is enought just to click with the mouse button on the map of that country. As a result, we can receive tourist attractions of the selected country - hotels, historical and cultural monuments, cafes and restaurants, as well as other information created for tourists and attracting them.

If Uzbekistan is selected from the list of countries, an interactive map of that country will be displayed. It shows the position, borders and territorial division of the Republic of Uzbekistan in Central Asia [3].

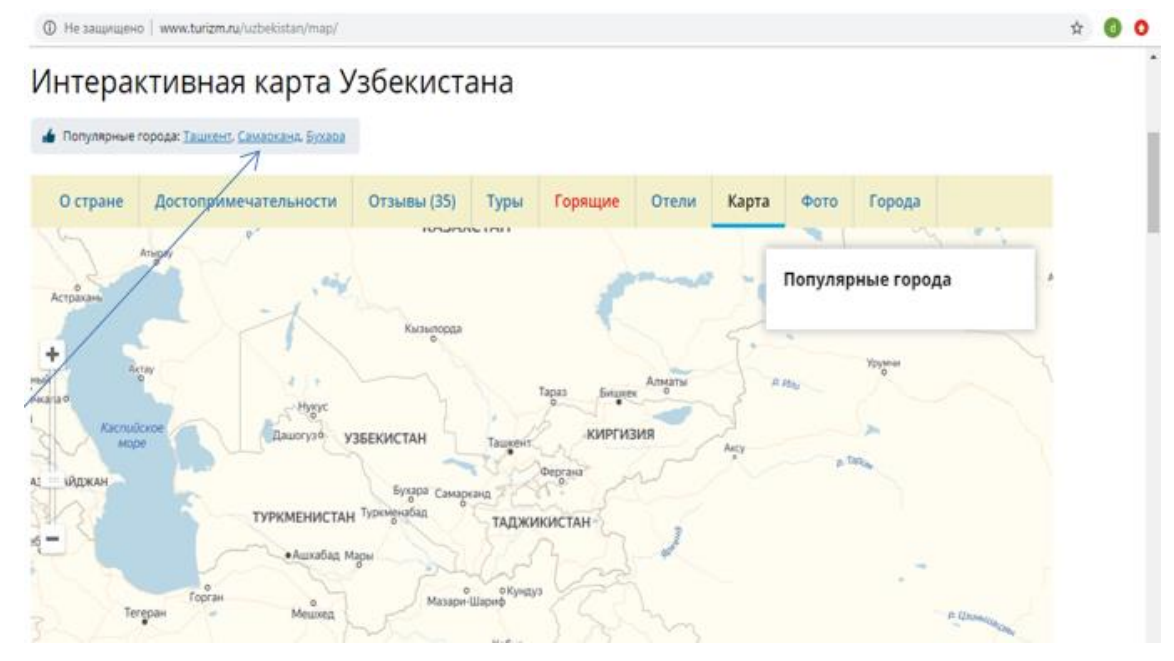

Figure 1. Interactive map of Uzbekistan 
In the north-west of the map are the names of famous tourist cities of Uzbekistan: Tashkent, Samarkand and Bukhara. If any of these are checked, the interactive map of that city will be displayed online.

\section{RESULTS AND DISCUSSION}

Using the indicator, we can see the status of Samarkand. The interactive map of Samarkand is one of the first essential tools for travelers. An interactive maps plays an important role, especially for tourists visiting and foreseeing the city's sights. Seeing, imagining and visiting the place is also fun. Interactive maps can also help us find our location [4].

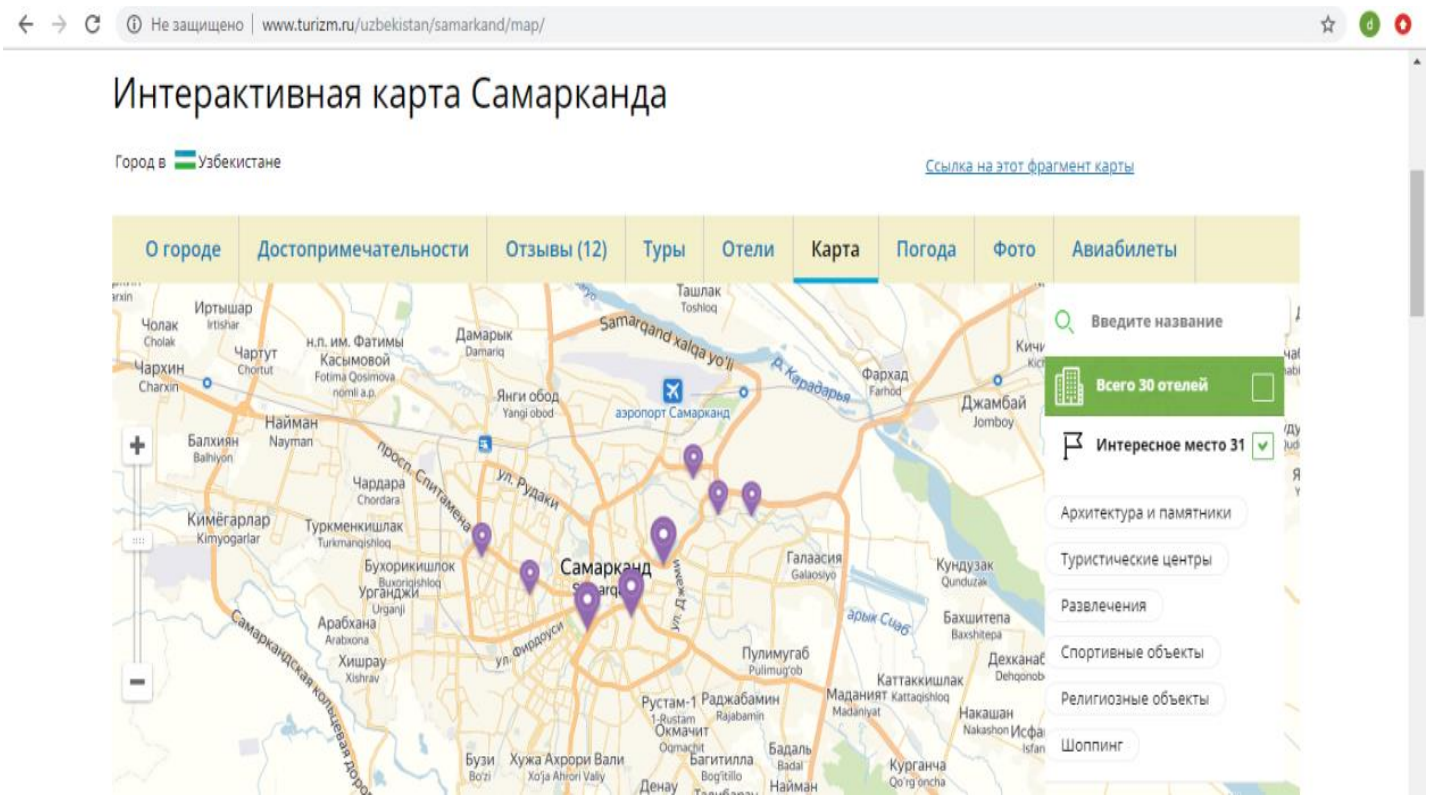

Figure 2. An interactive map of the city of Samarkand

Figure 2 depicts an interactive map of Samarkand with the use of symbols for hotels and attractions in the city (architectural monuments, tourist centers, markets, etc.). Click on the icon on the left to get information about that location. To the right of the map is a special legend for an interactive map. The legend shows the number of hotels and

attractions included on the map. As we can see, this map contains information about 30 hotels 
and 31 attractions. If we select a hotel section, all hotel icons will be displayed on the map. selection of the observatory built by the great astronaut Mirzo Ulugbek.

If select an interesting place, all the landmarks will appear on the map. On figure 3 shows the

Интерактивная карта Самарканда

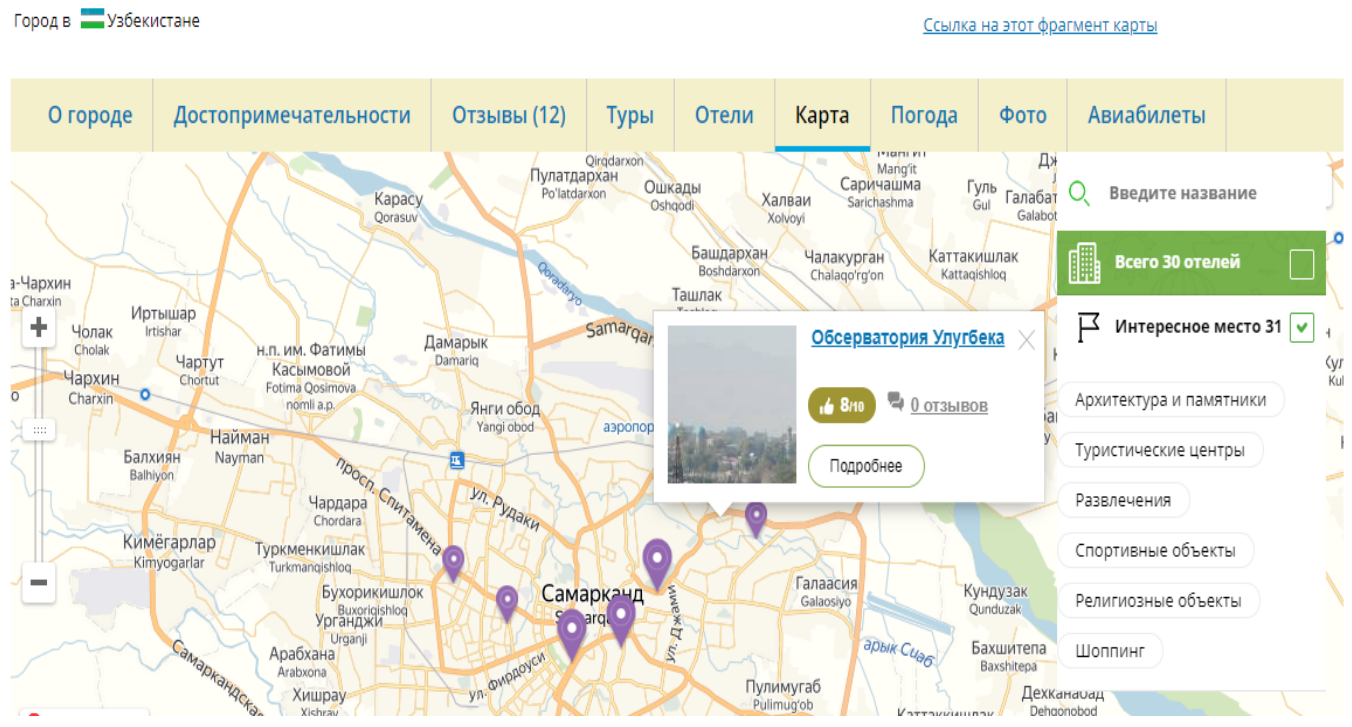

Figure 3. The status of the Ulugbek observatory on the interactive map.

It is known from history that after Mirzo Ulugbek became the khakim (mayor) of the city of Samarkand in 1409, and began to work on the improvement of the city and turning it into a center of science and culture. He invited some of the best scientists in mathematics and astronomy to Samarkand and ordered the construction of the observatory. In 1424-1428 a world-famous observatory was built in the north of Samarkand on the Kakhak hill along the Obirahmat ditch. Prior to that, scientific observations were conducted at Ulugbek madrasah, built in 1417-1420 (now Registan Square)[6].
The observatory is a three-storey, 30-m-tall building with cylinders, with a giant quadrant of 41 meters (an astronomical instrument for determining the height of the sun). The southern part of the quadrant is underground, with the remainder 30 meters above ground level in the north.

The museum still retains its originality and attractiveness. Ulugbek Observatory is one of the important monuments attracting foreign tourists. Visitors to the observatory can find out more about the observatory through the 
guides. Figure 4 shows a picture of the interior of the observatory in the online platform. The arrows to the right and to the left show a full picture of the interior and exterior of the
Ulughbek Observatory. There is also a statue of Mirzo Ulugbek in the photos.

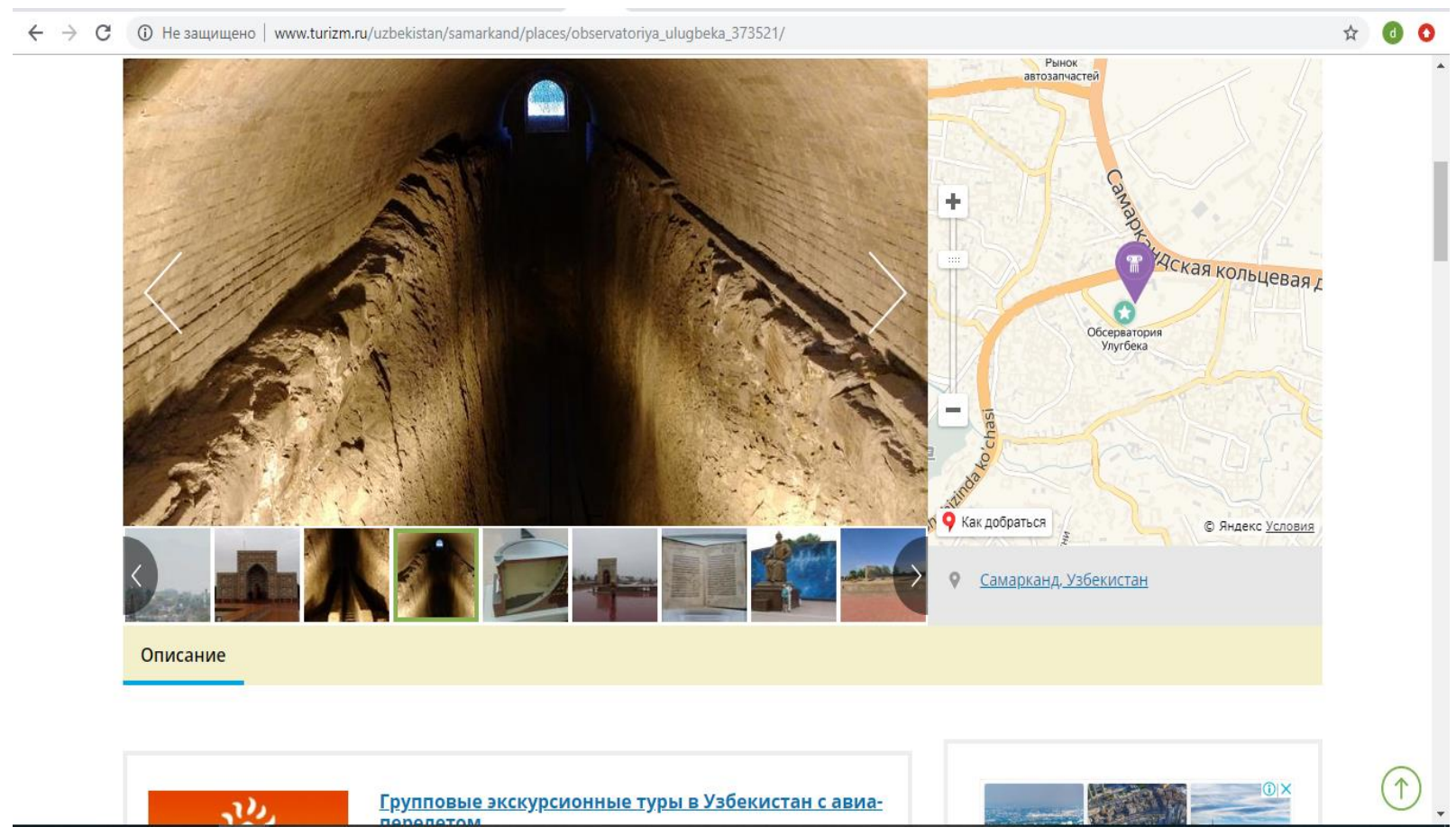

Figure 4. The interior of Ulugbek observatory.

This way, the icon on the map displays a picture of the historical monuments or hotels in the area. This will give the tourist or other users a good impression of the place. Interactive maps can also display information through images, text, links and other means. An interactive map of Samarkand can also be found on a mobile device.

\section{CONCLUSION}

In the age of techniques and technologies, consumers want a quick, easy and simple way to get the actual information they need. Thus, interactive maps can serve as an important actual cartographic source for quick access, which regularly updated in real time.

\section{REFERENCES}

1. Gulyamova L.X., Safarov E.Yu., Abdullayev I.O'. Geoaxborot tizimlari va texnologiyalari.

- Toshkent, $2013 \mathrm{y}$.

2. Safarov E.Yu., Abdurahimov X.A., Oymatov R.Q. Geoinformatsion kartografiya. Toshkent, $2012 \mathrm{y}$. 
3. Gulyamova L., Rahmonov D., Sattiyev Yu. Interaktiv dinamik kartografiyaning ayrim masalalari. O'zbekiston geografiya jamiyati axboroti, 46-jild. 2015 y. 207-211 b.

4. Suguru Ishizaki and Ishantha Lokuge. Intelligent Interactive Dynamic Maps, Visible Language Workshop, Media Laboratory Massachusetts Institute of Technology, pp 41-48, 2008.
5. Latif, S., \& Beck, F. (2019). Interactive map reports summarizing bivariate geographic data. Visual Informatics, 3(1), 27-37.

6. http://www.turizm.ru 